MAREK PARCHEM, WARSZAWA

\title{
KSIĘGA AMOSA W QUMRAN
}

Wśród zwojów odkrytych na Pustyni Judzkiej nad Morzem Martwym są fragmenty czterech biblijnych rękopisów Księgi Amosa (4Q78, 4Q82, 5Q4, Mur 88), cytaty wśród niebiblijnych zwojów qumrańskich (4Q174, 4Q387, CD) oraz peszer do Am 5,26-27 znajdujący się w CD 7,14-19.

\section{Biblijne rękopisy Księgi Amosa}

Wśród zwojów biblijnych odnalezionych na Pustyni Judzkiej nad Morzem Martwym fragmenty Księgi Amosa zachowały się w czterech zwojach, z których trzy rękopisy zawierają zbiór Dwunastu Proroków (4Q78, 4Q82, Mur 88), ${ }^{1}$ a jeden prezentuje tylko tekst Amosa (5Q4). Trzy manuskrypty zachowały się w Qumran, mianowicie w czwartej grocie (4Q78; 4Q82) oraz w piątej grocie (5Q4), natomiast jeden został odkryty w Wadi Murabba'at (Mur 88). ${ }^{2}$

1 W Qumran zbiór Dwunastu Proroków był przepisywany na jednym zwoju, zob. M. A b e g g, Jr., P. F 1 i n t, E. U $1 \mathrm{r}$ i c h, The Dead Sea Scrolls Bible: The Oldest Known Bible Translated for the First Time into English, New York 1999, s. 433; A. Tron in a, Biblia w Qumran. Wprowadzenie w lekturę biblijnych rękopisów znad Morza Martwego, BZ. TNT 8, Kraków 2001, s. 61.

2 Wydanie krytyczne tekstu Księgi Amosa stanowiącej część zwoju Dwunastu Proroków zostało opublikowane w serii Discoveries in the Judaean Desert (DJD) w następujących tomach: 4Q78 - R. E. F u 11 e r, 78. 4QXII c, w: E. U 1 r i c h, i in., Qumran Cave 4, X: The Prophets, DJD 15, Oxford 1997, s. 237-251 (+ pl. XLIV-XLVI); 4Q82 - t e nże, 82. 4QXII g, w: tamże, s. 271-318 (+ pl. XLIX-LXIV); 5Q4 - J. T. Mili k, 4. Amos, w: M. B a ille t, J. T. Mili k, R. deVa u X, Les „Petites Grottes” de Qumrân, Exploration de la falaise, Les grottes 2Q, 3Q, 5Q, 6Q, 7Q à 10Q, Le rouleau de cuivre, DJD 3, Oxford 1962, s. 173-174 (+ pl. XXXVI); Mur 88 - t e n ż e, 88. Rouleau des Douze Prophetes, w: P. B e n o i t, J. T. M i 1 i k, R. deVaux, Les grottes de Murabba'at, DJD 2, Oxford 1961, s. 181-205 (+ pl. 
Dane paleograficzne zwojów zawierających fragmentarycznie zachowany tekst Księgi Amosa wskazują, że jedna kopia została zapisana pismem hasmonejskim datowanym na lata 150-50 przed Chr. (4Q78), dwie kopie są zapisana pismem herodiańskim datowanym na lata 30 przed Chr. - 68 po Chr. (4Q82, 5Q4), natomiast rękopis z Wadi Murabba'at jest zapisany pismem poherodiańskim datowanym na lata 68-135 po Chr. (Mur 88).

Rękopisy z Pustyni Judzkiej nad Morzem Martwym zawierają fragmenty pochodzące $\mathrm{z}$ wszystkich dziewięciu rozdziałów biblijnej Księgi Amosa. Zawartość manuskryptów przedstawia się następująco: ${ }^{3}$

\begin{tabular}{|l|l|}
\hline 4Q78 (= 4QXII c) & Am 2,11-16; 3,1-2.4-7.8-15; 4,1-2; 6,13-14; \\
& 7,1-2.4.7-9.12-16 \\
\hline 4Q82 (= 4QXII g) & Am 1,3-7.9-15; 2,1.7-9.15-16; 3,1-2; 4,4-9; \\
& $5,1-2.9 .11-18 ; 6,1-4.6 .8-14 ; 7,1.7-12.14-17 ;$ \\
& $8,1-5.11-14 ; 9,1.6 .14-15$ \\
\hline 5Q4 (= 5QAmos) & Am 1,2-3(?).3-5 \\
\hline Mur 88 (= Mur XII) & Am 1,5-15; 2,1; 7,3-17; 8,3-7.11-14; 9,1-15 \\
\hline
\end{tabular}

LVI-LXXIII). Ponadto tekst Księgi Amosa w synoptycznym zestawieniu (tj. hebrajskie fragmenty z Qumran i Murabba'at; tekst masorecki i tekst grecki: LXX) został wydany w: B. E g o, A. L a n g e, H. L i c h t e n b e r g e r, K. d e Tr o y e r (red.), Biblia Qumranica: Minor Prophets, t. 3B, Leiden-Boston 2005, s. 47-69; zob. także wydanie tekstu Księgi Amosa w edycji elektronicznej: Biblical Dead Sea Scrolls, Bellingham 2010, Lexham Press (Logos Bible Software).

3 Zob. D. L. W a s h b u rn, A Catalog of Biblical Passages in the Dead Sea Scrolls, SBL. TCS 2, Leiden 2003, s. 144-145; B. E g o, A. L a n g e, H. L i c h t e nb e r g e r, K. d e Tr o y e r (red.), Biblia Qumranica: Minor Prophets, t. 3B, s. 47-69; P. M u c h o w s k i, Komentarze do rękopisów znad Morza Martwego, Seria Judaica i Hebraica 1, Poznań 2005, s. 371-372; zob. też A. Tro n in a, Biblia w Qumran, s. 30,36 . 
W zestawieniu z tekstem masoreckim Księgi Amosa, zachowane fragmenty z Pustyni Judzkiej nad Morzem Martwym przedstawiają się następująco: ${ }^{4}$

\begin{tabular}{|l|l|}
\hline $\begin{array}{l}\text { Tekst masorecki } \\
\text { (Biblia Hebrajska) }\end{array}$ & $\begin{array}{l}\text { Tekst z Pustyni Judzkiej } \\
\text { (4Q78, 4Q82, 5Q4, Mur 88) }\end{array}$ \\
\hline Am 1,2(?) & 5Q4 frag. 2-7 \\
\hline Am 1,3 & $\begin{array}{l}\text { 4Q82 frag. 30c, 40b-43b, 44; } \\
\text { 5Q4 frag. 1; frag. 2-7 }\end{array}$ \\
\hline Am 1,4 & $\begin{array}{l}\text { 4Q82 frag. 30c, 40b-43b, 44; } \\
\text { 5Q4 frag. 1 }\end{array}$ \\
\hline Am 1,5 & $\begin{array}{l}\text { 4Q82 frag. 30c, 40b-43b, 44; 5Q4 frag. 1; } \\
\text { Mur 88 kol. 3 }\end{array}$ \\
\hline Am 1,6 & 4Q82 frag. 30c, 40b-43b, 44; Mur 88 kol. 3 \\
\hline Am 1,7 & 4Q82 frag. 30c, 40b-43b, 44; Mur 88 kol. 3 \\
\hline Am 1,8 & 4Q82 frag. 30c, 40b-43b, 44; Mur 88 kol. 3 \\
\hline Am 1,9 & 4Q82 frag. 30c, 40b-43b, 44; Mur 88 kol. 3 \\
\hline Am 1,10 & 4Q82 frag. 30c, 40b-43b, 44; Mur 88 kol. 3 \\
\hline Am 1,11 & 4Q82 frag. 30c, 40b-43b, 44; Mur 88 kol. 3 \\
\hline Am 1,12 & 4Q82 frag. 30c, 40b-43b, 44; Mur 88 kol. 3 \\
\hline Am 1,13 & 4Q82 frag. 30c, 40b-43b, 44; Mur 88 kol. 3 \\
\hline Am 1,14 & 4Q82 frag. 30c, 40b-43b, 44; Mur 88 kol. 3 \\
\hline Am 1,15 & 4Q82 frag. 30c, 40b-43b, 44; Mur 88 kol. 3 \\
\hline Am 2,1 & 4Q82 frag. 30c, 40b-43b, 44; Mur 88 kol. 3 \\
\hline Am 2,7 & 4Q82 frag. 43a \\
\hline Am 2,8 & 4Q82 frag. 43a \\
\hline Am 2,9 & 4Q78 frag. 21-23a \\
\hline Am 2,11 & \\
\hline
\end{tabular}

4 Zob. Amos, ad loc., w: Biblical Dead Sea Scrolls (Logos Bible Software). 


\begin{tabular}{|l|l|}
\hline $\begin{array}{l}\text { Tekst masorecki } \\
\text { (Biblia Hebrajska) }\end{array}$ & $\begin{array}{l}\text { Tekst } \mathbf{z} \text { Pustyni Judzkiej } \\
\text { (4Q78, 4Q82, 5Q4, Mur 88) }\end{array}$ \\
\hline Am 2,12 & 4Q78 frag. 21-23 \\
\hline Am 2,13 & 4Q78 frag. 21-23 \\
\hline Am 2,14 & 4Q78 frag. 21-23 \\
\hline Am 2,15 & 4Q78 frag. 21-23; 4Q82 frag. 45-46 \\
\hline Am 2,16 & 4Q78 frag. 21-23; 4Q82 frag. 45-46 \\
\hline Am 3,1 & 4Q78 frag. 21-23; 4Q82 frag. 45-46 \\
\hline Am 3,2 & 4Q78 frag. 21-23; 4Q82 frag. 45-46 \\
\hline Am 3,4 & 4Q78 frag. 21-23 \\
\hline Am 3,5 & 4Q78 frag. 21-23 \\
\hline Am 3,6 & 4Q78 frag. 21-23 \\
\hline Am 3,7 & 4Q78 frag. 21-23 \\
\hline Am 3,8 & 4Q78 frag. 24-25, 48, 26-29 \\
\hline Am 3,9 & 4Q78 frag. 24-25, 48, 26-29 \\
\hline Am 3,10 & 4Q78 frag. 24-25, 48, 26-29 \\
\hline Am 3,11 & 4Q78 frag. 24-25, 48, 26-29 \\
\hline Am 3,12 & 4Q78 frag. 24-25, 48, 26-29 \\
\hline Am 3,13 & 4Q78 frag. 24-25, 48, 26-29 \\
\hline Am 3,14 & 4Q78 frag. 24-25, 48, 26-29 \\
\hline Am 3,15 & 4Q78 frag. 24-25, 48, 26-29 \\
\hline Am 4,1 & 4Q78 frag. 24-25, 48, 26-29 \\
\hline Am 4,2 & 4Q78 frag. 24-25, 48, 26-29 frag. 47a-48 kol. 1 \\
\hline Am 4,4 & 4Q82 frag. 47a-48 kol. 1 \\
\hline Am 4,5 & 4Q82 frag. 47a-48 kol. 1 \\
\hline Am 4,6 & \\
\hline Am 4,7 & 4Q82 frag. 47a-48 kol. 1 \\
\hline Am 4,8 & \\
\hline Am 4,9 & 47a-48 kol. 1 \\
\hline
\end{tabular}




\begin{tabular}{|l|l|}
\hline $\begin{array}{l}\text { Tekst masorecki } \\
\text { (Biblia Hebrajska) }\end{array}$ & $\begin{array}{l}\text { Tekst z Pustyni Judzkiej } \\
\text { (4Q78, 4Q82, 5Q4, Mur 88) }\end{array}$ \\
\hline Am 5,1 & 4Q82 frag. 49 \\
\hline Am 5,2 & 4Q82 frag. 49 \\
\hline Am 5,9 & 4Q82 frag. 47a-50 kol. 2 \\
\hline Am 5,10 & 4Q82 frag. 47a-50 kol. 2 \\
\hline Am 5,11 & 4Q82 frag. 47a-50 kol. 2 \\
\hline Am 5,12 & 4Q82 frag. 47a-50 kol. 2 \\
\hline Am 5,13 & 4Q82 frag. 47a-50 kol. 2 \\
\hline Am 5,14 & 4Q82 frag. 47a-50 kol. 2 \\
\hline Am 5,15 & 4Q82 frag. 47a-50 kol. 2 \\
\hline Am 5,16 & 4Q82 frag. 47a-50 kol. 2 \\
\hline Am 5,17 & 4Q82 frag. 47a-50 kol. 2 \\
\hline Am 5,18 & $\begin{array}{l}\text { 4Q82 frag. 47b, 51-52a, 53a-54a, 55-56a, } \\
\text { 57-58 }\end{array}$ \\
\hline Am 6,1 & $\begin{array}{l}\text { 4Q82 frag. 47b, 51-52a, 53a-54a, 55-56a, } \\
\text { 57-58 }\end{array}$ \\
\hline Am 6,2 & $\begin{array}{l}\text { 4Q82 frag. 47b, 51-52a, 53a-54a, 55-56a, } \\
\text { 57-58 }\end{array}$ \\
\hline Am 6,3 & $\begin{array}{l}\text { 4Q82 frag. 47b, 51-52a, 53a-54a, 55-56a, } \\
\text { 57-58 }\end{array}$ \\
\hline Am 6,4 & $\begin{array}{l}\text { 4Q82 frag. 47b, 51-52a, 53a-54a, 55-56a, } \\
\text { 57-58 }\end{array}$ \\
\hline Am 6,5 & $\begin{array}{l}\text { 4Q82 frag. 47b, 51-52a, 53a-54a, 55-56a, } \\
\text { 57-58 }\end{array}$ \\
\hline Am 6,6 & $\begin{array}{l}\text { 4Q82 frag. 47b, 51-52a, 53a-54a, 55-56a, } \\
\text { 57-58 }\end{array}$ \\
\hline Am 6,7 & \\
\hline Am 6,8 & 43a-54a, 55-56a, \\
\hline
\end{tabular}




\begin{tabular}{|c|c|}
\hline $\begin{array}{l}\text { Tekst masorecki } \\
\text { (Biblia Hebrajska) }\end{array}$ & $\begin{array}{l}\text { Tekst z Pustyni Judzkiej } \\
\text { (4Q78, 4Q82, 5Q4, Mur 88) }\end{array}$ \\
\hline Am 6,9 & $\begin{array}{l}\text { 4Q82 frag. 47b, 51-52a, 53a-54a, 55-56a, } \\
57-58\end{array}$ \\
\hline Am 6,10 & $\begin{array}{l}\text { 4Q82 frag. 47b, 51-52a, 53a-54a, 55-56a, } \\
57-58\end{array}$ \\
\hline Am 6,11 & $\begin{array}{l}\text { 4Q82 frag. 47b, 51-52a, 53a-54a, 55-56a, } \\
57-58\end{array}$ \\
\hline Am 6,12 & $\begin{array}{l}\text { 4Q82 frag. 47b, 51-52a, 53a-54a, 55-56a, } \\
57-58\end{array}$ \\
\hline Am 6,13 & $\begin{array}{l}\text { 4Q78 frag. 30-33; 4Q82 frag. 47b, 51-52a, } \\
\text { 53a-54a, 55-56a, 57-58 }\end{array}$ \\
\hline Am 6,14 & $\begin{array}{l}\text { 4Q78 frag. 30-33; 4Q82 frag. 47b, 51-52a, } \\
\text { 53a-54a, 55-56a, 57-58 }\end{array}$ \\
\hline Am 7,1 & $\begin{array}{l}\text { 4Q78 frag. 30-33; 4Q82 frag. 47b, 51-52a, } \\
\text { 53a-54a, 55-56a, 57-58 }\end{array}$ \\
\hline Am 7,2 & 4Q78 frag. $30-33$ \\
\hline Am 7,3 & Mur 88 kol. 7 \\
\hline Am 7,4 & 4Q78 frag. 30-33; Mur 88 kol. 7 \\
\hline Am 7,5 & 4Q78 frag. 30-33; Mur 88 kol. 7 \\
\hline Am 7,6 & Mur 88 kol. 7 \\
\hline Am 7,7 & $\begin{array}{l}\text { 4Q78 frag. 30-33; 4Q82 frag. 52b, 53b, 54b, } \\
\text { 56b, 59-60, 61-64 }\end{array}$ \\
\hline Am 7,8 & $\begin{array}{l}\text { 4Q78 frag. 30-33; 4Q82 frag. 52b, 53b, 54b, } \\
\text { 56b, 59-60, 61-64; Mur } 88 \text { kol. } 7\end{array}$ \\
\hline Am 7,9 & $\begin{array}{l}\text { 4Q78 frag. 30-33; 4Q82 frag. 52b, 53b, 54b, } \\
\text { 56b, 59-60, 61-64; Mur } 88 \text { kol. } 7\end{array}$ \\
\hline Am 7,10 & $\begin{array}{l}\text { 4Q78 frag. 30-33; 4Q82 frag. 52b, 53b, 54b, } \\
\text { 56b, 59-60, 61-64; Mur } 88 \text { kol. } 7\end{array}$ \\
\hline Am 7,11 & $\begin{array}{l}\text { 4Q78 frag. 30-33; 4Q82 frag. 52b, 53b, 54b, } \\
\text { 56b, 59-60, 61-64; Mur } 88 \text { kol. } 7\end{array}$ \\
\hline
\end{tabular}




\begin{tabular}{|c|c|}
\hline $\begin{array}{l}\text { Tekst masorecki } \\
\text { (Biblia Hebrajska) }\end{array}$ & $\begin{array}{l}\text { Tekst z Pustyni Judzkiej } \\
(4 Q 78,4 Q 82,5 Q 4, \text { Mur 88) }\end{array}$ \\
\hline Am 7,12 & $\begin{array}{l}\text { 4Q78 frag. 30-33; 4Q82 frag. 52b, 53b, 54b, } \\
\text { 56b, 59-60, 61-64; Mur } 88 \text { kol. } 7\end{array}$ \\
\hline Am 7,13 & $\begin{array}{l}\text { 4Q78 frag. 30-33; 4Q82 frag. 52b, 53b, 54b, } \\
\text { 56b, 59-60, 61-64; Mur } 88 \text { kol. } 7\end{array}$ \\
\hline Am 7,14 & $\begin{array}{l}\text { 4Q78 frag. 30-33; 4Q82 frag. 52b, 53b, 54b, } \\
\text { 56b, 59-60, 61-64; Mur } 88 \text { kol. } 7\end{array}$ \\
\hline Am 7,15 & $\begin{array}{l}\text { 4Q78 frag. 30-33; 4Q82 frag. 52b, 53b, 54b, } \\
\text { 56b, 59-60, 61-64; Mur } 88 \text { kol. } 7\end{array}$ \\
\hline Am 7,16 & $\begin{array}{l}\text { 4Q78 frag. 30-33; 4Q82 frag. 52b, 53b, 54b, } \\
\text { 56b, 59-60, 61-64; Mur } 88 \text { kol. } 7\end{array}$ \\
\hline Am 7,17 & $\begin{array}{l}\text { 4Q82 frag. 52b, 53b, 54b, 56b, 59-60, 61- } \\
\text { 64; Mur } 88 \text { kol. } 7\end{array}$ \\
\hline Am 8,1 & $\begin{array}{l}\text { 4Q82 frag. 52b, 53b, 54b, 56b, 59-60, 61- } \\
\text { 64; Mur } 88 \text { kol. } 7\end{array}$ \\
\hline Am 8,2 & 4Q82 frag. 52b, 53b, 54b, 56b, 59-60, 61-64 \\
\hline $\operatorname{Am~} 8,3$ & $\begin{array}{l}\text { 4Q82 frag. 52b, 53b, 54b, 56b, 59-60, 61- } \\
\text { 64; Mur } 88 \text { kol. } 7\end{array}$ \\
\hline Am 8,4 & $\begin{array}{l}\text { 4Q82 frag. 52b, 53b, 54b, 56b, 59-60, 61- } \\
\text { 64; Mur } 88 \text { kol. } 7\end{array}$ \\
\hline Am 8,5 & $\begin{array}{l}\text { 4Q82 frag. 52b, 53b, 54b, 56b, 59-60, 61- } \\
\text { 64; Mur } 88 \text { kol. } 7\end{array}$ \\
\hline Am 8,6 & Mur 88 kol. 7 \\
\hline $\operatorname{Am~8,7}$ & Mur 88 kol. 7 \\
\hline Am 8,11 & 4Q82 frag. 65-68; Mur 88 kol. 8 \\
\hline Am 8,12 & 4Q82 frag. 65-68; Mur 88 kol. 8 \\
\hline Am 8,13 & 4Q82 frag. 65-68; Mur 88 kol. 8 \\
\hline Am 8,14 & 4Q82 frag. 65-68; Mur 88 kol. 8 \\
\hline Am 9,1 & 4Q82 frag. 65-68; Mur 88 kol. 8 \\
\hline
\end{tabular}




\begin{tabular}{|l|l|}
\hline $\begin{array}{l}\text { Tekst masorecki } \\
\text { (Biblia Hebrajska) }\end{array}$ & $\begin{array}{l}\text { Tekst z Pustyni Judzkiej } \\
\text { (4Q78, 4Q82, 5Q4, Mur 88) }\end{array}$ \\
\hline Am 9,2 & Mur 88 kol. 8 \\
\hline Am 9,3 & Mur 88 kol. 8 \\
\hline Am 9,4 & Mur 88 kol. 8 \\
\hline Am 9,5 & 4Q82 frag. 69; Mur 88 kol. 8 \\
\hline Am 9,6 & 4Q82 frag. 69; Mur 88 kol. 8 \\
\hline Am 9,7 & Mur 88 kol. 8 \\
\hline Am 9,8 & Mur 88 kol. 8 \\
\hline Am 9,9 & Mur 88 kol. 8 \\
\hline Am 9,10 & Mur 88 kol. 8 \\
\hline Am 9,11 & Mur 88 kol. 8 \\
\hline Am 9,12 & Mur 88 kol. 8 \\
\hline Am 9,13 & Mur 88 kol. 8 \\
\hline Am 9,14 & 4Q82 frag. 70-75; Mur 88 kol. 8 \\
\hline Am 9,15 & 4Q82 frag. 70-75; Mur 88 kol. 8 \\
\hline
\end{tabular}

Rękopisy Księgi Amosa z Pustyni Judzkiej zawierają różne warianty tekstualne w stosunku do tekstu masoreckiego i LXX. Mając na uwadze pewne charakterystyczne cechy zwojów zawierających tekst Księgi Amosa, można stwierdzić, że 4Q78 reprezentuje tekst zbliżony do tradycji tekstualnej występującej w Septuagincie, natomiast 4Q82 jest bliski protomasoreckiej tradycji tekstualnej, przy czym w niektórych przypadkach różni się zarówno od tekstu masoreckiego, jak i od Septuaginty. Tekst w Mur 88 jest bardzo bliski tekstowi masoreckiemu, chociaż zdarzają się także pewne różnice. ${ }^{5}$

5 Zob. R. E. Fulle r, Minor Prophets, w: L. H. S c h iff m a n, J. C. V a n d e r K a $m$ i in. (red.), Encyclopedia of the Dead Sea Scrolls, t. I, Oxford 2000, s. 555-556; W. E. G1 e n n y, Finding Meaning in the Text: Translation Technique and Theology in the Septuagint of Amos, VTSup 126, Leiden 2009, s. 11-12. 
Większość różnic tekstualnych między tekstem masoreckim a tym, które prezentują zwoje z Pustyni Judzkiej, dotyczy ortografii i morfologii. Najważniejsze warianty tekstualne przedstawiają się następująco:

- Am 1,3 (TM): „Tak mówi JHWH: Z powodu trzech zbrodni Damaszku i z powodu czterech nie odwrócę tego (wyroku), gdyż zmłócili saniami żelaznymi Gilead". Tekst w 5Q4 dodaje słowo הרות, („ciężarne [kobiety]”) i czyta: „[... gdyż zmłócili saniami żelaznymi] ciężarne (kobiety) Gileadu" (frag. 1, linia 3; podobnie w LXX).

- Am 1,14 (TM): „I rozpalę ogień na murach Rabba, i pożre jej pałace wśród wrzasku w dniu bitwy, wśród wichru w dniu burzy". Tekst w 4Q82 wprowadza rodzajnik określony w słowie „bitwa”, tj. ,ta bitwa” i czyta: ,[w dniu] tej bitwy, [wśród wichru w dniu burzy]" (frag. 30c, 40b-43b, 44, linia 21).

- Am 2,13 (TM): „Oto Ja sprawię, że ugrzęźniecie tak, jak grzęźnie wóz wypełniony snopem”. W 4Q78 przed słowem „oto" na początku zdania dodaje się spójnik ,,i” ( והנה): „I oto, Ja sprawię, że ugrzęźniecie (...)" (frag. 21-23, linia 2).

- Am 2,16 (TM): „I mocny sercem swoim między bohaterami nago ucieknie w tym dniu, wyrocznia JHWH”. Zamiast słowa „mocny” (אמיץ), które znajduje się w tekście masoreckim, w 4Q78 pojawia się מוצא (,ten, który znajdzie”), czytając: „I ten, który znajdzie serce swoje ( ומוצ"א לבו)..." (frag. 21-23, linia 4; podobnie w LXX).

- Am 4,1 (TM): „Słuchajcie słowa tego, krowy Baszanu, które na górze Samarii gnębicie biedaków, uciskacie ubogich, mówiąc do mężów swoich: Przynieś, abyśmy mogli się napić!” Podczas gdy w tekście masoreckim występuje liczba pojedyncza, tj. הביאה (,przynieś!"’), to w 4Q78 jest liczba mnoga, tj. הביאו (,przynieście!”) (frag. 24-25, 48, 26-29, linia 9; podobnie w LXX).

- Am 5,15 (TM): „Nienawidźcie zła, a miłujcie dobro! I wymierzajcie w bramie sprawiedliwość! Może będzie łaskawy JHWH, Bóg zastępów, dla reszty Józefa". Podczas gdy w tekście masoreckim jest tryb rozkazujący שנאו („nienawidźcie!”) (qal imperat. m. pl.), to w 4Q82 występuje tryb oznajmujący שנאנו (,nienawidzimy”) (qal perf. pl.), czytając: „My nienawidzimy zła (...)” (frag. 47a, 50, kol. 2, linia 14; 
podobnie w LXX). Ponadto w 4Q82 do czasownika „być łaskawym” został dodany sufiks pierwszej osoby liczby mnogiej, tj. יחננ (,będzie łaskawy dla nas"), czytając: ,....) może będzie łaskawy dla nas JHWH, Bóg zastępów, dla reszty Józefa" (frag. 47a, 50, kol. 2, linia 15).

- Am 7,8 (TM): „I powiedział JHWH do mnie: Co widzisz, Amosie? I odpowiedziałem: Pion ołowiany. I powiedział Pan: Oto Ja kładę pion ołowiany w środek ludu mojego, Izraela. Nie powtórzę już przejścia dla niego”. W tekście 4Q82 zostało dodane słowo „Pan” ( ארוני), czytając „I powiedział Pan, JHWH, do mnie (...)” (frag. 52b, 53b, 54b, 56b, 59-60, 61-64, linia 1). Ponadto, podczas gdy w tekście masoreckim do słowa „oto” został dołączony sufiks zaimka osobowego pierwszej osoby liczby pojedynczej odnoszący się do Boga W הנני שם (,Oto Ja kładę...”) (tj. partykuła + sufiks + qal ptc. m. s.), to w 4Q78 występuje forma הנה שמתי („Oto kładę...”) (tj. partykuła + qal perf. s.) (frag. 30-33, linia 9).

- Am 7,15 (TM): „I wziął mnie JHWH od stada, i powiedział do mnie JHWH: Idź, prorokuj do ludu mojego, Izraela!’ W 4Q82 została opuszczona partykuła z sufiksem zaimka osobowego „do mnie” (tj. אלי (אי), czytając: ,(...) i powiedział JHWH: Idź (...)” (frag. 52b, 53b, 54b, 56b, 59-60, 61-64, linia 12). Ponadto, podczas gdy w tekście masoreckim jest partykuła אל (,do”) w wyrażeniu ,prorokuj do ludu mojego, Izraela!”, to w Mur 88 znajduje się partykuła על (,nad”) w zwrocie ,prorokuj nad ludem moim, Izraelem!” (kol. 7, linia 21).

- Am 7,16 (TM): „A teraz słuchaj słowa JHWH: Ty mówisz: Nie prorokuj przeciwko Izraelowi i nie przepowiadaj przeciwko domowi Izaaka!" W tekście Mur 88 zostało dodane wyrażenie ,już dłużej” (tj. עוד), czytając ,.... i nie przepowiadaj już dłużej przeciwko domowi Izaaka!" (kol. 7, linia 22).

- Am 7,17 (TM): „Dlatego tak powiedział JHWH: Żona twoja w mieście będzie uprawiała nierząd, a synowie twoi i córki twoje od miecza padną. I ziemię twoją sznurem podzielą. A ty umrzesz na ziemi nieczystej, Izrael zaś zostanie uprowadzony ze swojej ziemi". W tekście 4Q82 dodano słowo „Pan” ( אדני), czytając „[Dlatego tak mówi] Pan, JHWH: Ż[ona twoja (...)" (frag. 52b, 53b, 54b, 56b, 59-60, 61-64, linia 14). 
- Am 9,5 (TM): „I Pan, JHWH zastępów, dotyka ziemi, a ona topnieje, i lamentują wszyscy mieszkańcy na niej. I wzniesie się jak Nil wypełniony sobą, i opadnie jak Nil Egiptu". Podczas gdy w tekście masoreckim znajduje się wyrażenie ואבלו כל-יושבי בה (,i lamentują בה wszyscy mieszkańcy na niej”), to w Mur 88 pojawiają się słowa ואבל כל־יושב (,i lamentuje każdy mieszkaniec na niej”) (kol. 8, linia $15)$.

\section{Cytaty z Księgi Amosa w niebiblijnych zwojach z Qumran}

Księga Amosa jest cztery razy cytowana w pismach qumrańskich, mianowicie Am 9,11 w Midraszu dotyczącym czasów ostatecznych (4Q174 kol. 3, linia 12) oraz w Dokumencie Damasceńskim (CD 7,16); Am 8,11 w Apokryfie Jeremiasza C (4Q387 frag. 3, linie 8-9); Am 5,26-27 w Dokumencie Damasceńskim (CD 7,14-17). ${ }^{6}$ Oba cytaty znajdujące się w Dokumencie Damasceńskim są komentowane i tworzą swoistego rodzaju peszer do Księgi Amosa (CD 7,14-19), który zostanie omówiony poniżej w osobnym punkcie niniejszego opracowania.

\section{Q174 (4QMidrasz dotyczący czasów ostatecznych)}

Zachowało się dwadzieścia sześć fragmentów. Dane paleograficzne wskazują, że 4Q174 został napisany pismem wczesnoherodiańskim, które może być datowane na połowę I w. przed Chr. ${ }^{8}$ Zwój 4Q174, który dawniej był nazywany 4QFlorilegium, jest częścią

6 Zob. A. L a n g e, Biblical Quotations and Allusions in Second Temple Jewish Literature, Journal of Ancient Judaism Supplements 5, Göttingen 2011, s. 154-155.

7 Tekst opublikował J. M. A 11 e g r o, 174. Florilegium, w: t e n ż e, Qumran Cave 4. I (4Q158-4Q186), DJD 5, Oxford 1968, s. 53-57 (+ pl. XIX-XX); zob. też A. S t e u d e 1, Der Midrasch zur Eschatologie aus der Qumrangemeinde (4QMidrEschata. b). Materielle Rekonstruktion, Textbestand, Gattung und traditionsgeschichtliche Einordnung des durch 4Q174 (,,Florilegium”) und 4Q177 (,,Catena A”) repräsentierten Werkes aus den Qumranfunden, STDJ 13, Leiden 1994.

8 Zob. tamże, s. 202-210, 215. 
kompozycji, która obecnie nosi tytuł Midrasz dotyczacy czasów ostatecznych (4QMidrEschat a), Dokument należy do gatunku peszerów tematycznych, ponieważ składa się z cytatów biblijnych oraz komentarzy autora qumrańskiego. Treścią 4Q174 jest opis wydarzeń eschatologicznych, a więc tego, co wydarzy się ,przy końcu dni” (kol. 3, linie 2, 12, 15, 19; kol. 5, linia 3). ${ }^{9}$

Cytat z Księgi Amosa (Am 9,11) znajduje się w 4Q174 kol. 3, linii 12 jako część interpretacji tekstu z 2Sm 7,11-14 (linie 1-13).

W kompozycji tekstu 4Q174 kol. 3-4 można wyodrębnić dwie zasadnicze części, z których pierwsza stanowi komentarz do 2Sm 7,10-14 (linie 1-13), natomiast druga część jest komentarzem do Ps 1 i 2 (linie 14-kol. 4, linia 6?), Struktura kol. 3-4 przedstawia się następująco: ${ }^{10}$

I. Midrasz do 2Sm 7,10-14 (linie 1-13)

A. Odnośnie do eschatologicznej świątyni / wspólnoty (1-9)

1. Cytat z 2Sm 7,10-11a

2. Interpretacja i cytaty z Wj 15,17-18; $2 \mathrm{Sm} 7,11$

B. Odnośnie do eschatologicznych postaci (linie 10-13)

1. Cytat z 2Sm 7,11b-14a

2. Interpretacja i cytat z Am 9,11

II. Midrasz do Ps 1 i 2 (linia 14-kol. 4,6)
A. Formuła wprowadzająca
B. Midrasz do Ps 1

1. Cytat z Ps 1,1

2. Interpretacja i cytaty z Iz 8,11; Ez 37,23

C. Midrasz do Ps 2

1. Cytat z Ps 2,1-2

2. Interpretacja i cytaty z Dn 12,$10 ; 11,32$

9 Zob. G. J. B r o o k e, Florilegium, w: L. H. S c h if f m a n, J. C. V a n d e r K a m $\mathrm{i}$ in. (red.), Encyclopedia of the Dead Sea Scrolls, t. I, s. 297-298; P. M u c h o w s k i, Komentarze do rękopisów znad Morza Martwego, 137-139.

10 Zob. G. J. B ro o ke, Exegesis at Qumran: 4QFlorilegium in its Jewish Context, JSOTSup 29, Sheffield 1985, s. 164-165; C. D. E11 e d g e, The Bible and the Dead Sea Scrolls, SBL. ABS 14, Atlanta 2005, s. 76. 
Treść tekstu w 4Q174 kol. 3, liniach 10-13 stanowiącego midrasz dotyczący eschatologicznych postaci, w których znajduje się cytat z Am 9,11, przedstawia się następująco:

${ }^{10}$, ,[I po]wiedział do ciebie JHWH, że zbuduje dla ciebie dom. «I wywyższę potomstwo twoje po tobie, i ustanowię tron królestwa jego,

${ }^{11}$ [na za]wsze. Ja będę dla niego ojcem, a ono będzie dla mnie synem». On jest Odroślą Dawida, która powstanie z Wyjaśniającym Prawo, który

12 [powstanie] na Syjonie przy końcu dni, jak zostało napisane: «I sprawię, że podniesie się szałas Dawida, który upadł». On jest szałasem

${ }^{13}$ Dawida, który upadł, który powstanie, aby wybawić Izraela".

בתוב Cytat z Am 9,11 został wprowadzony za pomocą formuły כאר (,jak zostało napisane" - linia 12), która w 4Q174 służy do wprowadzenie cytatu biblijnego jako argumentu drugorzędnego. Innymi słowy, autor 4Q174 interpretując tekst w 2Sm 7, 11b-14a (tekst główny) umieszcza w komentarzu do niego własne wyjaśnienie wraz z cytatem z Am 9,11 (tekst drugorzędny) i jego interpretacją. Podobna sytuacja $\mathrm{z}$ identyczną formułą wprowadzającą cytat biblijny pojawia się w kol. 3, liniach 1-3, gdzie 2Sm 7,10-11a (tekst główny) jest komentowany przez użycie $\mathrm{Wj}$ 15,17-18 (tekst drugorzędny). Ponadto, formuła ,jak zostało napisane” wprowadzająca cytat z Am 9,11 wskazuje, że Księga Amosa była traktowana w Qumran jako pismo autorytatywne. ${ }^{11}$

11 Zob. M. J. B e r n s te I n, Reading and Re-Reading Scripture at Qumran, STDJ 107, t. 2, Leiden 2013, s. 655; zob. także J. d e W a a r d, A Comparative Study of the Old Testament Text in the Dead Sea Scrolls and in the New Testament, STDJ 4, Leiden 1965, s. 24-26; G. J. B r o o k e, Exegesis at Qumran: 4QFlorilegium in its Jewish Context, s. 114; szerzej na temat formuł wprowadzających cytaty biblijne w 4Q174, zob. A. S t e u d e 1, Der Midrasch zur Eschatologie aus der Qumrangemeinde, s. 141-142. Warto zauważyć, że cytat z Am 9,11 z identyczną formułą wprowadzającą pojawia się w Dz 15,15-16. 
Cytat z Am 9,11 w 4Q174 kol. 3, linii 12 różni się nieco od tekstu masoreckiego, przy czym występujące różnice nie wpływają na znaczenie, które pozostaje takie samo.

4Q174 kol. 3, linia 12:

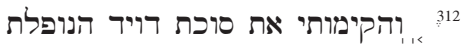

„I sprawię, że podniesie się szałas Dawida, który upadł”.

Am 9,11 (tekst masorecki):

„I podniesie się szałas Dawida, który upadł”.

9י" , אקים את־סכת רויד הנפלת

W dwóch przypadkach różnica dotyczy ortografii i stanowi charakterystyczną cechę qumrańskiej praktyki pisania, która polega na używaniu matres lectionis, a więc stosowanie scriptio plena, mia-

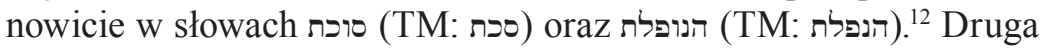
różnica dotyczy formy czasownika קום (,podnieść się”, „powstać”, „ustanowić”), podczas gdy w 4Q174 słowo to występuje w hifil perfectum $\mathrm{w}$ konstrukcji z waw conversivum, to w tekście masoreckim jest w hifil imperfectum.

Cytat z Am 9,11 w 4Q174 kol. 3, linii 12 jest częścią komentarza do tekstu z 2Sm 7,11b-14a, który zawiera zapowiedź pomyślności dla potomków (tj. dynastii) Dawida. W kontekście Księgi Amosa, tekst z Am 9,11 jest częścią zakończenia biblijnej księgi (9,11-15) będącego dodatkiem późniejszego redaktora, którego treścią jest pełna nadziei obietnica odnosząca się do przyszłości, mianowicie zapowiedź odrodzenia dynastii Dawida, odnowienia królestwa i rozszerzenia jego panowania (ww. 11-12) oraz pomyślności dla narodu Izraela (ww. 13-15). ${ }^{13} \mathrm{~W}$ interpretacji tekstu z 2Sm 7,11b-14a autor

12 Zob. E. T o v, Textual Criticism of the Hebrew Bible, Minneapolis-Assen 2001, s. 108-109; E. D. R e y m o n d, Qumran Hebrew: An Overview of Orthography, Phonology, and Morphology, SBL. RBS 76, Atlanta 2014, s. 35-43; szerzej na temat qumrańskiej praktyki pisania, zob. E. T o v, Scribal Practices and Approaches Reflected in the Texts Found in the Judean Desert, STDJ 54, Leiden 2004.

13 Zob. K. E. P o m y k a l a, The Davidic Dynasty Tradition in Early Judaism: Its History and Significance for Messianism, SBL. EJIL 7, Atlanta 1995, s. 61-63; J. J e r e m i a s, The Book of Amos: A Commentary, OTL, Louisville 1998, s. 160-169; 
qumrański stwierdza, że צמח דויד (,Odrośl Dawida” - tytuł mesjański, zob. Jr 23,5; 33,15; 4Q161 frag. 7-10, kol. 3, linia 22; 4Q252 kol. 5, linie 3-4; 4Q285 frag. 5, linia 3) powstanie razem z Wyjaśniającym Prawo (tytuł mesjański w Qumran, zob. CD 6,7; 7,18) przy końcu dni. Podczas gdy „Odrośl Dawida” jest tytułem odnoszącym się do Mesjasza królewskiego, tj. pochodzącego z dynastii Dawida, to postać określona jako דורש התורה (,Wyjaśniający Prawo”) najprawdopodobniej odnosi się do Mesjasza kapłańskiego. Oczekiwanie na dwie postacie, tj. Mesjasza królewskiego i Mesjasza kapłańskiego, jest odzwierciedleniem oczekiwań mesjańskich wspólnoty z Qumran (zob. Mesjasz „,z Aarona i z Izraela” w 1QS 9,9-11; CD 12,23-13,1; 14,19; 20,1; 1QSa 2,11-14.17-22). Autor 4Q174 identyfikuje „Odrośl Dawida” jako וכת דויד (,szałas Dawida”), wyrażając w ten sposób myśl, że Mesjasz królewski z dynastii Dawida powstanie na Syjonie, aby wybawić Izraela. ${ }^{14}$

J. D. N o g a ls k i, Literary Precursors to the Book of the Twelve, BZAW 217, Berlin-New York 1993, s. 97-122; t e n ż e, The Day(s) of JHWH in the Book of the Twelve, w: P. L. Red dit t, A. S c hart(red.), Thematic Threads in the Book of the Twelve, BZAW 325, Berlin-New York 2003, s. 206-207; M. L. B a r r e, Ksiega Amosa, w: R. E. B r ow n i in. (red.), Katolicki komentarz biblijny, Prymasowska Seria Biblijna 17, Warszawa 2001, s. 832-833.

14 Zob. B. G är $\mathrm{t} \mathrm{n}$ e r, The Temple and the Community in Qumran and the New Testament: A Comparative Study in the Temple Symbolism of the Qumran Texts and the New Testament, Society for New Testament Studies, Monograph Series 1, Cambridge 1965, s. 40-41; G. J. B r o o k e, Exegesis at Qumran: 4QFlorilegium in its Jewish Context, s. 138-139; t e n ż e, Florilegium, s. 297; G. G. X e r a v it s, King, Priest, Prophet: Positive Eschatological Protagonists of the Qumran Library, STDJ 47, Leiden 2003, s. 55-57; C. D. E $11 \mathrm{e}$ d g e, The Bible and the Dead Sea Scrolls, s. 77; J. J. C o 11 i n s, Apocalypticism in the Dead Sea Scrolls, LDSS, London-New York 1997, s. 84;t e n ż e, The Scepter and the Star: Messianism in Light of the Dead Sea Scrolls, Grand Rapids-Cambridge 2010, s. 82, 184-185; D. D i m a n t, 4QFlorilegium and the Idea of the Community as a Temple, w: t e $\mathrm{n} \dot{\mathrm{z}} \mathrm{e}$, History, Ideology and Bible Interpretation in the Dead Sea Scrolls, FAT 90, Tübingen 2014, s. 284-285. 


\section{Q387 (4QApokryf Jeremiasza C) ${ }^{15}$}

Zachował się on w czterech fragmentach. Badania paleograficzne wskazują, że dokument został napisany pismem późnohasmonejskim lub wczesnoherodiańskim, który może być datowany na lata 50-25 przed Chr. ${ }^{16}$ Treścią Apokryfu Jeremiasza, mającego charakter apokaliptyczny i ujętego w formę mowy Boga skierowanej do Jeremiasza, jest ukazanie historii Izraela od czasów najdawniejszych aż po okres Drugiej Świątyni i prawdopodobnie kończącej się na opisie wydarzeń eschatologicznych. ${ }^{17}$

Księga Amosa (Am 8,11) jest cytowana w 4Q387 frag. 3, liniach 8-9. Zachowana treść tego fragmentu przedstawia się następująco (linie 1-9):

,${ }^{1}[\ldots]$ ołtarz $[\ldots]$

${ }^{2}[\ldots$ ci, którzy u]padli od [miecza...]

${ }^{3}[\ldots]$ splugawiona $[\ldots]$

${ }^{4}[\ldots]$ trzej kapłani, którzy nie kroczą drogą

5 [kapłanów] wcześniejszych, którzy przez imię Boga Izraela zostali wezwani.

${ }^{6}$ [I zostanie strącona w] ich dniach pycha tych, którzy postępują niegodziwie wobec przymierza i służą obcemu.

${ }^{7}$ I zostanie rozdarty Izrael w tym pokoleniu, walcząc jeden przeciw drugiemu,

15 Tekst opublikowała D. D i m a n t, zob. t a ż, 387. 4QApocryphon of Jeremiah Cb, w: t a ż, Qumran Cave 4. XXI: Parabiblical Texts, Part 4: Pseudo-Prophetic Texts, DJD 30, Oxford 2001, s. 173-199 (+ pl. VII-VIII).

16 Zob. $\mathrm{t}$ a ż, 4QApocryphon of Jeremiah: Introduction, w: tamże, s. 93-94; P. M u c h o w s k i, Komentarze do rękopisów znad Morza Martwego, s. 293; K. D a $\mathrm{v}$ i s, The Cave 4 Apocryphon of Jeremiah and the Qumran Jeremianic Traditions: Prophetic Persona and the Construction of Community Identity, STDJ 111, Leiden 2014, s. 94-95, jest zdania, że zwój 4Q387 jest zapisany pismem herodiańskim i jego powstanie powinno być datowane na okres od 30 r. przed Chr. do 30 r. po Chr., najprawdopodobniej na początek I w. po Chr.

17 Zob. tamże, s. 157-174; zob. także B. H. R e y n o 1 d s III, Between Symbolism and Realism: The Use of Symbolic and Non-Symbolic Language in Ancient Jewish Apocalypses 333-63 B. C. E., Journal of Ancient Judaism Supplements 8, Göttingen 2011, s. 263-286. 
${ }^{8}$ z powodu Prawa i z powodu przymierza. «I ześlę głód na ziemię, lecz nie

${ }^{9}$ chleba, i pragnienie, lecz nie wody, [ty]lko [słuchania słowa mojego]»".

Cytat z Am 8,11 został wprowadzony bezpośrednio, bez jakiejkolwiek formuły wprowadzającej i różni się nieco od tekstu masoreckiego.

4Q387a frag. 3, linie 8-9:

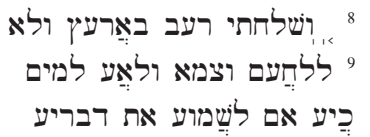

„I ześlę głód na [zie]mię, lecz nie

chl[e]ba, i pragnienie, lecz ni[e] wody,

[ty]lko [słuchania słowa mojego]".

Am 8,11 (tekst masorecki):

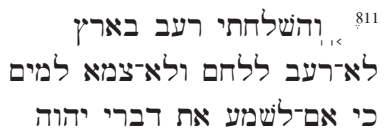

„I spowoduję zesłanie głodu na ziemię,

nie głodu chleba, i nie pragnienia wody, tylko słuchania słów JHWH".

W 4Q387a został zmieniony tekst Am 8,11 poprzez dodanie spójnika ,il” przed pierwszym przeczeniem i usunięcie następującego po nim słowa „głód” (רעב), które w tekście masoreckim występuje dwa razy. Ponadto, w tekście masoreckim Am 8,11 czasownik (,wלח (,wsłać"), jest w formie hifil ( השלחתי, hifil perf. 1 s.), natomiast w 4Q387a ma formę qal ( שלחתי, qal perf. 1 s.), co jednak nie wpływa zasadniczo na jego znaczenie. Końcowa część tekstu w linii 9 nie zachowała się, ale podczas gdy w tekście masoreckim Am 8,11 znajdują się słowa „tylko słuchania słów JHWH”, to w tekście qumrańskim D. Dimant proponuje jego rekonstrukcję jako „tylko słuchania słowa mojego". ${ }^{18}$

18 D. D i m a n t, 387. 4QApocryphon of Jeremiah Cb, s. 194; K. D a v i s, The Cave 4 Apocryphon of Jeremiah and the Qumran Jeremianic Traditions, s. 154-155. 
Cytowany w 4Q387 tekst z Am 8,11 jest częścią rozdziału 8, którego treścią jest wizja, w której Amos widzi kosz owoców (ww. 1-3), po której następują groźby i upomnienia proroka przeciwko nadużyciom społecznym (ww. 4-8) oraz opis kary Bożej (ww. 9-14). Groźba zapowiadająca nadejście ,głodu (...) słuchania słów JHWH” (w. 11) jest jednym z elementów kary Bożej, ponieważ ten głód nie będzie zaspokojony: „I będą błąkać się od morza do morza, i z północy na wschód będą krążyli, aby szukać słowa JHWH, ale nie znajdą" (w. 12). Motyw głogu i pragnienia pojawia się często w tradycji biblijnej jako obraz kary, którą Bóg wymierzy Izraelowi za niewierność wobec przymierza (np. Pwt 28,48; 2Krn 32,11; Iz 5,13; $\mathrm{Ne} 9,15)$. Według proroka Amosa, zapowiedź niezaspokojonego głodu słuchania słowa Bożego oznacza, że Bóg odwróci się od Izraela i nie będzie dłużej wysłuchiwał próśb swego narodu z powodu łamania przez niego przymierza. Izrael utraci kontakt z Bogiem z powodu swoich grzechów wobec Boga i lekceważenia słów proroków. Innymi słowy, Izrael zostanie pozbawiony słowa Bożego będącego źródłem życia i wszelkiej pomyślności (zob. Pwt 8,3). ${ }^{19}$

W 4Q387 frag. 3, linie 8-9 cytat z Am 8,11, będący częścią „wyroczni zapowiadającej karę wobec Izraela", pojawia się w kontekście wzmianki o grzechach mających charakter kultyczny, kapłanach i karze wymierzonej tym, którzy postępują niegodziwie wobec przymierza. ${ }^{20}$ Tekst 4Q387 frag 3 zachował się w stanie fragmentarycznym, dlatego też istnieją poważne trudności w jego interpretacji. Wielu uczonych uważa, że tekst tego fragmentu opisuje w formie proroctwa ex eventu czasy machabejskie, a więc tzw. reformę hellenistyczną wprowadzoną przez Antiocha Epifanesa, której rezultatem

19 Zob. J. L. M a y s, Amos: A Commentary, OTL, Philadelphia 1969, s. 148-149; G. v o n R a d, Teologia Starego Testamentu, tłum. B. W i d ł a, Warszawa 1986, s. 435; G. W it a s z e k, Amos: Prorok sprawiedliwości społecznej, Lublin 1996, s. 163-164; J. J e r e m i a s, The Book of Amos: A Commentary, s. 150-151.

20 Zob. M. A b e g g, Jr., P. F 1 in t, E. U 1 r i c h, The Dead Sea Scrolls Bible, s. 432; H. v o n W e i s s e n b e r g, The Twelve Minor Prophets at Qumran and the Canonical Process: Amos as a „Case Study” w: N. D a v i d i in. (red.), The Hebrew Bible in Light of the Dead Sea Scrolls, FRLANT 239, Göttingen 2012, s. 372. 
były prześladowania i zbezczeszczenie świątyni, odstępstwo zhellenizowanych Żydów, powstanie pod wodzą Machabeuszy i początkowy okres panowania władców z dynastii hasmonejskiej. ${ }^{21} \mathrm{Na}$ takie rozumienie wskazują występujące w 4Q387 frag. 3 wyrażenia, które przywołują na myśl podobne sformułowania pojawiające się w Dn 10-11, m. in. „,[.. ci, którzy u]padli od [miecza...]” (linia 2; por. Dn 11,33), „ci, którzy postępują niegodziwie wobec przymierza” (linia 6; zob. Dn 11,32; 1QM 1,2; por. Dn 11,30: „ci, którzy opuścili święte przymierze"). Jednak pojawiają się różnice w odniesieniu do interpretacji szczegółów oraz identyfikacji osób i zdarzeń wspomnianych w 4Q387 frag. 3. Wzmianka o „trzech kapłanach, którzy nie kroczą drogą [kapłanów] wcześniejszych" (linie 4-5) odnosi się najprawdopodobniej do Machabeuszy, którzy byli kapłanami (zob. 1Mch 2,1-5), być może do Matatiasza, Judy Machabeusza i Jonatana, którzy rozpoczęli powstanie przeciwko Seleucydom i dali początek panowaniu dynastii hasmonejskiej. ${ }^{22}$ Są oni przeciwstawieni „,[kapłanom] wcześniejszym", których być może należy identyfikować jako zhellenizowanych arcykapłanów sprawujących swój urząd

${ }^{21}$ Zob. np. D. D i m a n t, 387. 4QApocryphon of Jeremiah Cb, s. 193; L. H. S c h if $\mathrm{fm}$ a n, The Concept of Covenant in the Qumran Scrolls and Rabbinic Literature, w: t e n ż e, Qumran and Jerusalem: Studies in the Dead Sea Scrolls and the History of Judaism, SDSSRL, Grand Rapids-Cambridge 2010, s. 250; K. D a $\mathrm{v}$ i s, The Cave 4 Apocryphon of Jeremiah and the Qumran Jeremianic Traditions, s. 163-164.

${ }^{22}$ Tak uważa K. Davis, zob. tamże, s. 164; zob. też B. A d a m c z e w s k i, 'Ten Jubilees of Years'. Heptadic Calculations of the End of the Epoch of Iniquity and the Evolving Ideology of the Hasmoneans, w: H. D r a w n e 1, A. P i w o w a r (red.), Qumran. Pomiędzy Starym a Nowym Testamentem, Analecta Biblica Lublinensia 2, Lublin 2009, s. 123, który mówi ogólnie o „faithful Maccabean priests”; zob. szerzej M. O. W is e, 4Q245 (4QpsDan c ar) and the High Priesthood of Judas Maccabaeus, DSD 12/2005, s. 352-359; J. C. V a n d e r K a m, From Joshua to Caiaphas: High Priests after the Exile, Minneapolis 2004, s. 240-244; warto zauważyć, że Józef Flawiusz wzmiankuje, iż Juda Machabeusz pełnił funkcje arcykapłańskie (Antiquitates, 12,413.426). Natomiast D. D i m a n t, 387. 4QApocryphon of Jeremiah $C b$, s. 193, sądzi, że chodzi o późniejszych władców hasmonejskich, mianowicie Szymona, Jana Hirkana i Aleksandra Janneusza. 
w ostatnich latach panowania Seleucydów. ${ }^{23}$ Według 4Q387 frag. 3, wraz z pojawieniem się „trzech kapłanów” machabejskich (linia 4) nastąpi ,,[strącenie w] ich dniach pychy tych, którzy postępują niegodziwie wobec przymierza i służą obcemu" (linia 6). Wyrażenie ,strącenie pychy” wydaje się nawiązywać do rezultatu zbrojnego powstania pod wodzą Machabeuszy, które było skierowane nie tylko przeciwko Seleucydom, ale również przeciw zhellenizowanym Żydom, na co wskazują słowa o tym, że ,zostanie rozdarty Izrael w tym pokoleniu, walcząc jeden przeciw drugiemu z powodu Prawa i z powodu przymierza" (linie 7-8).

Trudno jednoznacznie stwierdzić, w jakim znaczeniu cytat z Am 8,11 pojawia się w 4Q387 frag. 3. Z jednej strony, sens cytatu z Am 8,11 - tj. niezaspokojony głód słowa Bożego - może być podobny jak w biblijnej Księdze Amosa, a więc wyrażając karę polegającą na odwróceniu się Boga od tych, którzy spośród Izraela dokonali apostazji i niegodziwie postępowali wobec przymierza. ${ }^{24}$ Wydaje się jednak, że bardziej słuszne jest stwierdzenie, iż autor 4Q387, cytując Am 8,11, zmienia jego pierwotny sens przez nadanie mu znaczenia pozytywnego, które odnosi się do kapłanów machabejskich. Ich działalność zakończyła okres deprawacji i bezbożności, a równocześnie rozpoczęła czas wierności wobec Boga i przestrzegania zobowiązań płynących z przymierza. Innymi słowy, „głód słuchania słowa Bożego" staje się synonimem gorliwości religijnej i oznacza pragnienie bycia wiernym Bogu poprzez zachowywanie przymierza. ${ }^{25}$

Warto zauważyć, że w 4Q387 frag. 3 - oprócz cytatu z Am 8,11 pojawia się jeszcze jedna aluzja do Księgi Amosa, mianowicie słowo

${ }^{23}$ Zob. K. D a vis, The Cave 4 Apocryphon of Jeremiah and the Qumran Jeremianic Traditions, s. 163-164.

24 Tak sugeruje H. vo n W e is s e n b e r g, The Twelve Minor Prophets at Qumran and the Canonical Process: Amos as a „Case Study”, s. 373.

${ }_{25}$ Tak K. D a v is, The Cave 4 Apocryphon of Jeremiah and the Qumran Jeremianic Traditions, s. 164; zob. t e $\mathrm{n} \dot{\mathrm{z}} \mathrm{e}$, Torah Performance and History in the Golah: Rewritten Bible or „Re-presentational” Authority in the Apocryphon of Jeremiah c, w: P. W. F 1 in $\mathrm{t}$ i in. (red.), Celebrating the Dead Sea Scrolls, A Canadian Collection, SBL. EJIL 30, Atlanta 2011, s. 480. 
גאון (,,pycha”, wyniosłość”) (frag. 3, linia 6) występuje także w Am 8: „Przysiągł JHWH na pychę Jakuba: Nie zapomnę nigdy wszystkich ich czynów" (w. 7). ${ }^{26}$

\section{Peszer do Księgi Amosa w CD 7,14-19}

Wśród zwojów z Qumran odkryto grupę pism stanowiących komentarze (tj. peszery) do ksiąg biblijnych, zwłaszcza prorockich, w którym cytuje się tekst biblijny, a następnie interpretuje się go, aktualizując treść biblijną do czasów współczesnych komentatorowi qumrańskiemu. Wyodrębniono w tej grupie tzw. peszery ciągłe (np. komentarze do Ha - 1QpHab; Mi - 1Q14; So - 1Q15; 4Q170; Iz 4Q161-165; Oz - 4Q166-167; Na - 4Q169; Ps - 1Q16; 4Q171; 4Q173) i tzw. peszery tematyczne (np. Midrasz dotyczący czasów ostatecznych: 4Q174, 4Q177; Midrasz eschatologiczny Melchizedek: 11Q13). ${ }^{27}$ Wśród peszerów qumrańskich D. Dimant wyszczególniła jeszcze jedną kategorię, mianowicie tzw. peszery wyodrębnione, które składają się z jednego lub więcej cytatów pochodzących z ksiąg biblijnych

26 Zob. M. B r a d y, Biblical Interpretation in the 'Pseudo-Ezekiel' Fragments (4Q383-391) from Cave Four, w: H. H e n z e (red.), Biblical Interpretation at Qumran, SDSSRL, Grand Rapids 2005, s. 101; jak słusznie zauważa E. Z a w is z e w s k i, Księga Amosa. Wstęp, przekład, komentarz, PŚST XII/1, Poznań 1968, s. 245, termin gaōn w Am 8,7 ma znaczenie negatywne, tj. ,pycha”, „wyniosłość”, dlatego całkowicie chybione jest tłumaczenie całego wyrażenia jako „,majestat Jakuba” (tak tłum. M. Szmajdziński w przekładzie interlinearnym pod red. A. Kuśmirek), „duma Jakuba" (tłum. Z. Kaznowski w Biblii Tysiąclecia; tłum. K. Marklowski w Biblii Poznańskiej), „chwała Jakuba” (nieznany autor tłumaczenia w Biblii Paulistów).

27 Rozróżnienia na peszery ciągłe i tematyczne jako pierwszy dokonał J. C a r m i g n a c, Le document de Qumrân sur Melkisédeq, RQ 7/1969-1971, s. 360-361, co przyjęli również inni uczeni; zob. np. M. P. H o r g a n, Pesharim: Qumran Interpretations of Biblical Books, CBQMS 8, Washington 1979, s. 2-3; S. M ę d a 1 a, Peszery qumrańskie i midrasze starożytnego judaizmu, CT 63(1993)3, s. 29-31; D. W. P a r r y, E. To v (red.), Exegetical Texts, The Dead Sea Scrolls Reader 2, Leiden 2004, s. XXI-XXII; szerzej na temat peszerów w apekcie gatunku literackiego oraz stosowanych w nich metod i technik egzegetycznych, zob. S. L. B e r r i n, Qumran Pesharim, w: M. H e n z e (red.), Biblical Interpretation at Qumran, s. 110-133. 
wraz z ich interpretacją na sposób ,peszerowy”, ale nie stanowią one odrębnych dokumentów, tylko są częścią tekstów reprezentujących odmienne od typowych peszerów gatunki literackie. Najwięcej tzw. peszerów wyodrębnionych pojawia się w Dokumencie Damasceńskim, np. peszer do Oz w CD 1,13-14; peszer do Ez 44,15 w CD 3,21-4,4; peszer do Iz 24,17 w CD 4,13-19; peszer do Ma 1,10 w CD 6,12-14; peszer do Iz 7,17 w CD 7,9-13; peszer do Am 5,26-27 w CD 7,14-19; peszer do Za 13,7 w CD 19,5-13, ale występują również w innych zwojach, m.in. w Regule zrzeszenia, np. peszer do Iz 40,3 w 1QS 8,13-15. ${ }^{28}$

Zgodnie z zaproponowaną przez D. Dimant poszerzoną klasyfikacją peszerów qumrańskich, tekst znajdujący się Dokumencie Damasceńskim (CD 7,14-19) można uważać za peszer do Am 5,26-27. ${ }^{29}$

28 Zob. D. D i m a n t, Qumran Sectarian Literature, w: M. E. S t o n e (red.), Jewish Writings of the Second Temple Period: Apocrypha, Pseudepigrapha, Qumran Sectarian Writings, Philo, Josephus, CRINT III/2, Assen-Philadelphia 1984, s. 504-505; t a ż, Pesharim, Qumran, w: D. N. F r e e d m a n i in. (red.), The Anchor Bible Dictionary, New York 1992, s. 248. Propozycję poszerzonej klasyfikacji peszerów qumrańskich zaakceptowało wielu uczonych, np. G. J. B r o o k e, Pesher, w: R. J. C o g g i n s, J. L. H o u 1 d e n (red.), A Dictionary of Biblical Interpretation, London 1990, s. 532; L. H. S c h i f f m a n, Reclaiming the Dead Sea Scrolls: The History of Judaism, the Background of Christianity, the Lost Library of Qumran, Philadelphia 1994, s. 224; t e n ż e, Biblical Exegesis in the Passion Narratives and the Dead Sea Scrolls, w: I. K a 1 i m i, P. J. H a s s (red.), Biblical Interpretation in Judaism and Christianity, LHB. OTS 439, New York 2006, s. 119; A. A s c h i m, The Genre of 11QMelchizedek, w: F. H. C r y e r, T. L. T h o m p s o n (red.), Qumran between the Old and New Testaments, Sheffield 1998, 21, 25; I. F r ö h 1 i c h, Qumran Names, w: D. W. P a r r y, E. U $1 \mathrm{r}$ i c h (red.), The Provo International Conference on the Dead Sea Scrolls: Technological, Innovations, New Texts, and Reformulated Issues, STDJ 30, Leiden 1999, s. 304; T. H. L i m, Pesharim, Companion to the Qumran Scrolls, London-New York 2002, s. 47-48; J. G. C a m p b e 11, The Exegetical Texts, Companion to the Qumran Scrolls, London-New York 2004, 12-14.

29 Zob. D. D i m a n t, Qumran Sectarian Literature, s. 505; G. J. B r o o k e, Shared Exegetical Traditions between the Scrolls and the New Testament, w: T. H. L i m, J. J. C o 11 i n s (red.), The Oxford Handbook of the Dead Sea Scrolls, Oxford 2010, s. 577; T. H. L i m, Pesharim, s. 48; zob. także S. L. B e r r i n, Pesharim, w: L. H. S c h if f m a n, J. C. V a n d e r K a m i in. (red.), Encyclopedia of the Dead Sea Scrolls, t. II, Oxford 2000, s. 646. 
Tekst CD 7,14-19 przedstawia się następująco: ${ }^{30}$

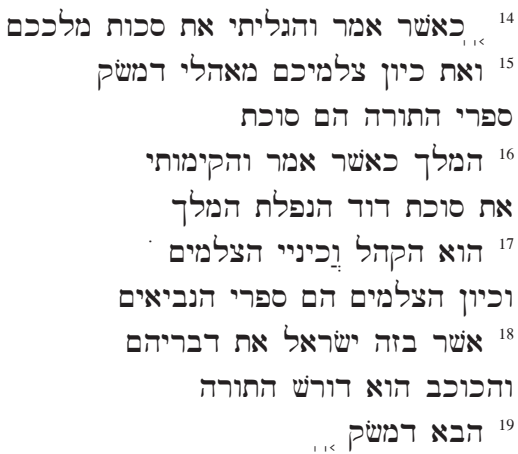

${ }^{14}$ (...) Jak powiedział: «I wygnam skwt króla waszego

${ }^{15}$ i kjwn obrazów waszych z namiotu mojego (do) Damaszku».

Księgi Prawa to szałas (swkt)

${ }^{16}$ króla, jak powiedział: «I sprawię, że podniesie się

szałas Dawida, który upadł». Król

${ }^{17}$ to zgromadzenie, \{i podstawy obrazów\}

i kjwn obrazów to księgi proroków,

${ }^{18}$ których słowami wzgardził Izrael.

I gwiazda to Wyjaśniający Prawo,

${ }^{19}$ który przyjdzie do Damaszku (...)"

W kontekście poprzedzającym peszer do Am 5,26-27 znajdujący się w CD 7,14-19 jest mowa o tym, że gdy rozłączyły się dwa domy Izraela, tj. Efraim i Juda, niektórzy zginęli, będąc wydanymi pod miecz, a ci, którzy przetrwali, uciekli do ,ziemi północy”, tj. do Damaszku (CD 7,12-14). Po tym stwierdzeniu autor Dokumentu Damasceńskiego cytuje Am 5,26-27, a następnie interpretuje go, dostrzegając wypełnienie się słów proroka Amosa w odniesieniu

30 Zob. J. M. B a u m g a r t e n, D. R. S c h w a r tz, Damascus Document (CD), w: J. H. C h a r l e s w o r t h i in. (red.), The Dead Sea Scrolls. Hebrew, Aramaic, and Greek Texts with English Translations, PTSDSSP, t. 2: Damascus Document, War Scroll, and Related Documents, Tübingen-Louisville 1995, s. 26; tłum. pol., por. P. M u c h ow s k i, Rękopisy znad Morza Martwego. Qumran, Wadi Murabba'at, Masada, Nachal Chewer, BZ. TNT 5, Kraków 2000, s. 204. 
do wydarzenia z historii wspólnoty, mianowicie ucieczkę do Damaszku. ${ }^{31}$ Trudno jednoznacznie stwierdzić, co oznacza nazwa „Damaszek” (lub „ziemia Damaszku”). Niektórzy uczeni rozumieją ją w sensie dosłownym, a więc jako okolice Damaszku w Syrii, niektórzy, odwołując się do identyfikacji „Damaszku” z ,ziemią północy”, uważają, że chodzi o Babilon, a jeszcze inni sądzą, że jest to nazwa symboliczna i odnosi się do „Qumran”, „pustyni”, „świątyni”. ${ }^{32} \mathrm{Bez}$ względu jednak na przyjmowaną hipotezę w odniesieniu do znaczenia słowa „Damaszek” czy ewentualnej lokalizacji miejsca ucieczki wspólnoty, jest pewne, że autor CD podział pokoleń Izraela interpretuje i aktualizuje jako odnoszący się do odłączenia się wspólnoty esseńskiej w łonie judaizmu okresu Drugiej Świątyni.

Cytat z Am 5,26-27 został wprowadzony za pomocą formuły כאשר אמר (,jak powiedział”) (linia 14), która łączy cytowany tekst biblijny z tym, co go poprzedza, a więc komentarzem do Iz 7,17. Innymi słowy, cytat z Am 5,26-27 stanowi kontynuację dłuższego wywodu autora na temat pewnych wydarzeń z początków historii wspólnoty. ${ }^{33}$ Autor CD, cytując Am 5,26-27, opuszcza część tekstu

31 Zob. J. A. Fit z m y e r, The Use of Explicit Old Testament Quotations in Qumran Literature and in the New Testament, NTS 7/1961, s. 321; B. Z. W a c h o 1 de r, The New Damascus Document. The Midrash on the Eschatological Torah of the Dead Sea Scrolls: Reconstruction, Translation and Commentary, STDJ 56, Leiden 2007, s. 237-238.

32 Przegląd różnych hipotez na temat znaczenia słowa „Damaszek” w Dokumencie Damasceńskim, zob. J. M u r p h y - O' C o n n o r, Damascus, w: L. H. S c h iffm a n, J. C. Va n d e r K a m i in. (red.), Encyclopedia of the Dead Sea Scrolls, t. II, s. $165-166$.

33 Niektórzy uczeni wyodrębniają w tekście Dokumentu Damasceńskiego „midrasz do Izajasza-Amosa-Księgi Liczb” w CD 7,10-8,1, zob. S. H u 1 t g r e n, From the Damascus Covenant to the Covenant of the Community: Literary, Historical, and Theological Studies in the Dead Sea Scrolls, STDJ 66, Leiden 2007, s. 29-39; G. G. X e r a v it s, King, Priest, Prophet: Positive Eschatological Protagonists of the Qumran Library, s. 43-45. 
biblijnego i zmienia jego sens, co wynika z niezrozumienia przez niego dwóch słów, mianowicie סכיון $[\mathrm{skwt}] \mathrm{kjwn}] .{ }^{34}$

CD 7,14-15 (= Am 5,26-27):

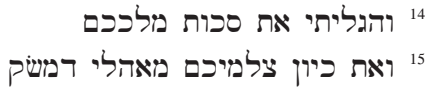

${ }^{14}$ I wygnam SKWT króla waszego

${ }^{15}$ i KJWN obrazów waszych z namiotu mojego (do) Damaszku". Am 5,26-27 (tekst masorecki):

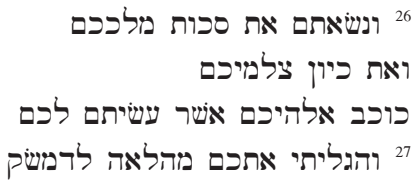

${ }^{26}{ }^{26}$ nosiliście SKWT, króla waszego,

i KJWN, podobizny wasze,

[gwiazdę bogów waszych, które uczyniliście dla siebie].

${ }^{27}$ I wygnam was poza Damaszek (...)"

W cytowanym w CD 7,14-15 tekście z Am 5,26-27 zachodzą dość znaczne różnice $\mathrm{w}$ porównaniu $\mathrm{z}$ tekstem biblijnym. Zamiast początkowego wyrażenia ונשאתם (,,i nosiliście”), po którym w tekście biblijnym następują słowa „skwt króla waszego” (w. 26), autor CD umieszcza na początku słowo והגליתי (,,i wygnam”) z wiersza następnego (w. 27). W CD zostaje opuszczony zwrot צלמיכם (,podobizny wasze”), a zamiast biblijnego wyrażenia מהלאה (,,poza”, tj. ,daleko”) pojawia się מאהלי (,z namiotu mojego"). Co więcej, autor peszeru opuszcza końcową część w. 26, tj. ,gwiazda boga waszego, którego uczyniliście dla siebie".

W Am 5,26-27 prorok mówi o praktykowanej przez Izraelitów idolatrii w kontekście obszerniejszej mowy piętnującej błędne traktowanie kultu (5,21-27). Kluczowymi dla właściwego zrozumienia sensu Am 5,26-27 są dwa terminy, mianowicie סיון oba

34 Zob. B. J. R o b e r t s, Some Observations on the Damascus Document and the Dead Sea Scrolls, BJRL 34/1951-1952, s. 373; J. A. F it z m y e r, The Use of Explicit Old Testament Quotations in Qumran Literature, s. 322. 
słowa zostały przez masoretów opatrzone znakami samogłoskowymi

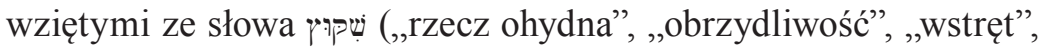
„odraza”), które w tradycji biblijnej jest określeniem wyobrażeń bóstw (np. 1Krl 11,5.7; 2Krl 23,13), lub kultu im oddawanego (np. Pwt 29,16; Iz 66,3; Jr 7,30; Ez 5,11; Dn 9,27; 11,31; 12,11). Termin סכות (TM:

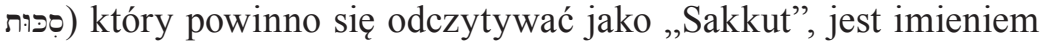

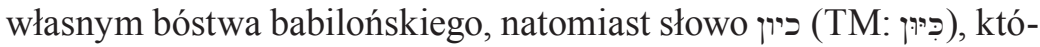
rego właściwa wymowa powinna brzmieć „Kajwan”, jest babilońską nazwą planety Saturn (tj. Kajjamanu) i bóstwa z nią związanego. Istnieje również możliwość, że słowo pochodzi od semickiego *sikkantu (,stela”), zaś słowo כיון wywodzi się od rdzenia כון i może oznaczać „piedestał, podstawę (posągu)". ${ }^{35}$ Jednak bez względu na konkretne znaczenie słów ככות [skwt] [ כיון [ $[k j w n]$, czy chodzi o bóstwa astralne, czy też o przedmioty kultu, można z całą pewnością stwierdzić, że prorok Amos wypowiada się w sposób negatywny krytykując i potępiając idolatrię praktykowaną przez Izraelitów.

Tymczasem autor Dokumentu Damasceńskiego oba słowa, mianowicie כתוין [skwt] [ כיון $[\mathrm{kjwn}]$, interpretuje w znaczeniu pozytywnym. Biblijny termin סכות [skwt], „Sakkut” łączy ze słowem „król” i odczytuje jako וכת המלך (,,szałas króla”), interpretując ów סוכת (,szałas”) jako „Księgi Prawa”, co uzasadnia cytatem z Am 9,11: „I sprawię, że podniesie się szałas Dawida [ ספכַּ] דויד], który upadł" (7,15-16). Warto zauważyć, że cytat z Am 9,11 różni się - podobnie jak w 4Q174 kol. 3, linia 12 - od tekstu biblijnego w odniesieniu do formy czasownika קום (,podnieść się”, ,powstać”, ,ustanowić”), podczas gdy w CD 7,16 słowo to występuje w hifil perfectum $\mathrm{w}$ konstrukcji $\mathrm{z}$ waw conversivum ( והקימותי), to w tekście masoreckim jest w hifil imperfectum

35 Zob. H. M. B a r st a d, The Religious Polemics of Amos: Studies in the Preaching of Am 2, 7B-8; 4, 1-13; 5, 1-27; 6, 4-7; 8, 14, VTSup 34, Leiden 1984, s. 118-126; O. L o r e t z, Die babylonischen Gottesnamen Sukkut und Kajjamanu in Amos 5,26, ZAW 101/1989, s. 286-289; C. d e M o o r, Standing Stones and Ancestor Worship, UF 27/1995, s. 1-20; M. S to 1, Kaiwan, w: K. van de r To orn i in. (red.), Dictionary of Deities and Demons in the Bible, Leiden 1999, s. 478; t e n ż e, Sakkuth, w: tamże, s. 722-723; J. R a d i n e, The Book of Amos in Emergent Judah, FAT II/45, Tübingen 2010, s. 60-67. 
(אקים). W pozytywny sposób autor Dokumentu Damasceńskiego interpretuje również termin כיון [kjwn], „Kajwan”, który identyfikuje jako „Księgi proroków” (7,17). Trudno stwierdzić, dlaczego autor CD interpretuje „szałas” jako „Księgi Prawa”. S. Hulgren sugeruje, że myśl interpretacji jest taka, iż Bóg zesłał na wygnanie „Księgi Prawa”, które „wpadły” w zaniedbanie i zlekceważenie w Judzie (zob. cytat z Am 9,11). Tora została więc przeniesiona ze świątyni do „Damaszku”, gdzie zostanie „ustanowiona” na nowo dla wspólnoty esseńskiej, z którą Bóg na wygnaniu zawrze przymierze. ${ }^{36}$ Warto zauważyć, że autor CD zamiast biblijnego wyrażenia מהלאה (,poza”, tj. „daleko”) odnoszącego się do zesłania na wygnanie do Damaszku, wprowadza zwrot מאהלי (,z namiotu mojego"), co bez wątpienia nawiązuje do myśli o sanktuarium. Być może znał on tradycję identyfikującą sanktuarium/świątynię z Torą, lub w szerszym znaczeniu z Pismem Świętym. ${ }^{37} \mathrm{~W}$ ten sposób autor peszeru do Am 5,26-27 umiejscawia na wygnaniu w „Damaszku” zawarcie przez Boga ze wspólnotą esseńską przymierza, które polega na zachowaniu i właściwej interpretacji Prawa i Proroków, tj. Pisma Świętego. Innymi słowy, autor CD odczytywał tekst znajdujący się w Am 5,26-27 jako proroctwo dotyczące tego, że na wygnaniu Księgi Prawa i proroków zostaną odnowione, tj. zostanie im przywrócony należyty szacunek, a ich prawdziwa interpretacja zostanie objawiona, co stanie się dzięki działalności Nauczyciela sprawiedliwości (zob. CD 6). ${ }^{38}$

W CD 7,17-18 stwierdza się, że „Izrael wzgardził słowami” znajdującymi się w księgach proroków, co stanowi aluzję do 2Krn 36,15-16:

36 Zob. S. Hu ltg re n, From the Damascus Covenant to the Covenant of the Community, s. 98-99.

37 Zob. N. W i e d e r, Sanctuary as a Metaphor for Scripture, JJS 8/1957, s. 165 -175; E. C o t h e n e t, Le Document de Damas, w: J. C a r m i g n a c, E. C o t h e net, H. Lig n e e (red.), Les Textes de Qumran. Traduits et annotés, t. II, Paris 1963, s. 172; L. M o r a ld i, I manoscritti di Qumran, Classici delle religioni 2, La religione ebraica, Torino 1971, s. 244; zob. też L. H. S c h i ff m a n, The Halakhah at Qumran, SJLA 16, Leiden 1975, s. 31-32; S. H u $1 \mathrm{tg}$ r e n, From the Damascus Covenant to the Covenant of the Community, s. 98-99.

38 Zob. tamże, s. 97; zob. też E. C o th e n e t, Le Document de Damas, s. 172. 
„I JHWH, Bóg ojców ich, nieustannie wysyłał do nich przez posłańców swoich (...). Lecz oni byli tymi, którzy szydzą z posłańców Boga, i tymi, którzy gardzą słowami Jego, i tymi, którzy lekceważą proroków Jego (...)”. W rezultacie takiego postępowania, Bóg „sprowadził na nich króla Chaldejczyków" (2Krn 36,17). Aluzja do 2Krn 36,15-17 wskazuje, że autor Dokumentu Damasceńskiego nawiązuje do niewoli babilońskiej, a zwłaszcza jej przyczyn, a następnie interpretuje to wydarzenie, aktualizując je w odniesieniu do sytuacji wspólnoty esseńskiej. Podczas gdy przed niewolą Izrael ,gardził” słowami proroków, to w niewoli istniała wspólnota, która szanowała, zachowywała i interpretowała słowa wysłanników Boga, jak to czyniła wspólnota esseńska na wygnaniu w „Damaszku” (CD 7,16). ${ }^{39}$ Warto zwrócić uwagę, że autor peszeru do Am 5,26-27 najpierw identyfikuje ,,szałas króla” jako „Księgi Prawa” (CD 7,15-16), a następnie stwierdza, że קהל "królem” jest „zgromadzenie” (CD 7,16-17). Użyty tutaj termin oznacza w czasach powygnaniowych zgromadzenie o charakterze liturgicznym (zob. Ne 8,2; 2Krn 29,23; 30,2), a w Dokumencie Damasceńskim odnosi się do wspólnoty esseńskiej (CD 12,6). Według autora peszeru do Am 5,26-27, wspólnota strzeże i interpretuje Księgi Prawa, tj. Torę. ${ }^{40}$ Możliwe, że autor CD używa wyrażenia nie w sensie ,i wygnam”, ale w znaczeniu „i objawię”, wyrażając prawdę, iż Bóg na wygnaniu objawił prawdziwą interpretację Prawa i Proroków, tj. Pisma Świętego, którą powierzył Nauczycielowi sprawiedliwości (zob. CD 3,12-16; 6,2-11). ${ }^{41}$

W ostatniej części peszeru do Am 5,26-27 autor interpretuje termin „gwiazda” (CD 7,18-19), stwierdzając, że ,gwiazdą jest Wyjaśniający Prawo, który przyjdzie do Damaszku”. W cytowanym tekście biblijnym z Księgi Amosa autor CD opuszcza słowa ,gwiazdę bogów waszych, które uczyniliście dla siebie" (w. 26), które stanowią

39 Zob. S. Hultg re n, From the Damascus Covenant to the Covenant of the Community, s. 99; zob. też E. C o th e n e t, Le Document de Damas, s. 173.

40 Zob. tamże, s. 172-173.

${ }_{41}$ Zob. L. H. S c h if f m a n, The Halakhah at Qumran, s. 31-32; S. H u $1 \mathrm{tg}$ r e n, From the Damascus Covenant to the Covenant of the Community, s. 99. 
kontekst komentarza w Dokumencie Damasceńskim. ${ }^{42}$ Zamiast słów z Am 5,26 odnoszących się do bóstwa astralnego łączonego z Saturnem, autor CD interpretuje słowo ,gwiazda” za pomocą cytatu z Lb 24,17. Najpierw stwierdza, że ,gwiazdą” jest רורש התורה (,Wyjaśniający Prawo" - CD 7,18), a następnie,wykorzystując tekst w Lb 24,17 („wschodzi gwiazda z Jakuba, i powstaje berło z Izraela”), interpretuje „,berło” jako „Księcia całego zrzeszenia”, który zwycięży wrogów (CD 7,20-21). Najwięcej trudności w interpretacji tekstu w CD 7,19 wzbudza wzmianka o Wyjaśniającym Prawo, „który przyjdzie [הבא] do Damaszku". Niektórzy uczeni interpretują słowo הבא (qal participium) w odniesieniu do przeszłości, tj. ,który przyszedł”, powołując się na tekst w CD 6,7, gdzie o Wyjaśniającym Prawo jest mowa w odniesieniu do przeszłości. ${ }^{43}$ Natomiast inni uczeni uważają, że słowo הבא odnosi się do przyszłości i tłumaczą je w znaczeniu „który przyjdzie”, identyfikując osobę Wyjaśniającego Prawo jako postać eschatologiczną. Należy zauważyć, że z gramatycznego punktu widzenia obie interpretacje są możliwe, ponieważ forma imiesłowowa czasownika jest bezczasowa i może wyrażać przeszłość, teraźniejszość, ale także przyszłość. Co więcej, jak zauważa J. J. Collins, w pismach qumrańskich tytułem „Wyjaśniający Prawo" są obdarzane różne osoby w odmiennym znaczeniu czasowym. Według 1QS 6,6, każda grupa składająca się z dziesięciu osób powinna mieć wśród siebie osobę, która będzie „wyjaśniała

42 Brak wzmianki o gwieździe w cytowanym tekście z Am 5,26-27 może być rezultatem błędu w przekazie tekstu Dokumentu Damasceńskiego, zob. J. A. F it z m y e r, The Use of Explicit Old Testament Quotations in Qumran Literature, s. 322; G. G. X e r a vit s, King, Priest, Prophet: Positive Eschatological Protagonists of the Qumran Library, s. 45.

${ }^{43}$ Warto jednak zwrócić uwagę, że tekst w CD 6,7 należy do odrębnej jednostki literackiej (CD 6,2-11), która została dołączona do Dokumentu Damasceńskiego w późniejszym etapie redakcji tego dzieła, zob. J. M u r p h y - O' C o n no r, A Literary Analysis of Damascus Document VI,2-VIII,3, RB 78/1971, s. 228-232; G. G. X e r a v it s, King, Priest, Prophet: Positive Eschatological Protagonists of the Qumran Library, s. 46. 
Prawo" ( איש דורש בתורה). ${ }^{44}$ Wydaje się, że w odróżnieniu od tekstu w CD 6,7, gdzie postać Wyjaśniającego Prawo jest osobą historyczną, mogącą być identyfikowaną z Nauczycielem sprawiedliwości z CD 1,11, to wzmianka o Wyjaśniającym Prawo w CD 7,18 odnosi się do przyszłości i jest określeniem postaci mesjańskiej. ${ }^{45} \mathrm{Na}$ takie rozumienie wskazuje jej połączenie z interpretacją tekstu znajdującego się w Lb 24,17, mającego zwykle konotacje eschatologiczne, ${ }^{46}$ gdzie termin „berło” interpretuje się jako „Księcia całego zrzeszenia”, który w pismach qumrańskich jest ukazany jako postać mesjańska (np. 1QSb 5,20; 1QM 5,1-2; 4Q285 frag. 4, linie 1-10). ${ }^{47}$ Co więcej, W sensie mesjańskim i eschatologicznym postać Wyjaśniającego Prawo pojawia się również w 4Q174, kol. 3, liniach 11-12, który jest blisko związany z Dokumentem Damasceńskim. ${ }^{48}$ Uzasadnione więc

${ }^{44}$ Zob. J. J. C o 11 i n s, The Scepter and the Star, s. 112-113.

45 Tak uważają, np. E. C o th e n e t, Le Document de Damas, s. 172-173; G. J. B r o o ke, The Messiah of Aaron in the Damascus Document, RQ 15/1991, s. 224-227; M. A. K n i b b, The Interpretations of Damascus Document VII,9b-VIII, $2 a$ and XIX,5b-14, RQ 15/1991, s. 249-250; t e $\mathrm{n} \dot{\mathrm{z}} \mathrm{e}$, Interpreter of the Law, w: L. H. S ch iffm a n, J. C. Va n d e r K a m i in. (red.), Encyclopedia of the Dead Sea Scrolls, t. I, s. 384; G. G. X e r a v it s, King, Priest, Prophet: Positive Eschatological Protagonists of the Qumran Library, s. 46; F. G a r c i a M a r t i n e z, Balaam in the Dead Sea Scrolls, w: G. H. va n K o ot e n, J. T. A. G. M. $\mathrm{v}$ a $\mathrm{n} \mathrm{R}$ u it e n (red.), The Prestige of a Pagan Prophet Balaam in Judaism, Early Christianity and Islam, Themes in Biblical Narrative 11, Leiden 2008, s. 80-81; J. J. C o 11 i n s, The Scepter and the Star, s. 88; A. K u ś m i r e k, Balaam i jego wyrocznie (Lb 22-24) w tradycji targumicznej, RSB 42, Warszawa 2011, s. 61-62.

$46 \mathrm{Na}$ temat eschatologicznej i mesjańskiej interpretacji tekstu w Lb 24,17, zob. S. B e y e r l e, „, A Star Shall Come out of Jacob”: A Critical Evaluation of the Balaam Oracle in the Context of Jewish Revolts in Roman Times, w: G. H. v a n K o o t e n, J. T. A. G. M. v a n R u it e n (red.), The Prestige of a Pagan Prophet Balaam in Judaism, Early Christianity and Islam, s. 163-188; J. J. C o 11 i n s, The Scepter and the Star, s. 71-73.

47 Szerzej zob. M. P a r c h e m, Ostateczne zwycięstwo Boga w walce między dobrem a złem w świetle pism z Qumran, RSB 30, Warszawa 2008, s. 301-312.

48 Zob. J. C o 11 i n s, The Scepter and the Star, s. 112; na temat wzajemnych relacji istniejących między 4Q174 a CD, zob. G. J. B r o o k e, Exegesis at Qumran: 4QFlorilegium in its Jewish Context, s. 206-207. 
wydaje się przypuszczenie, że w CD 7,18-21 - podobnie jak w 4Q174 kol. 3, liniach 11-12 - jest mowa o oczekiwaniu na dwie postacie eschatologiczne, co jest wyrazem mesjańskich nadziei wspólnoty, mianowicie tytuł „Wyjaśniający Prawo” najprawdopodobniej odnosi się do Mesjasza kapłańskiego, natomiast „Książę całego zrzeszenia” jest określeniem Mesjasza królewskiego. ${ }^{49}$

Odnalezione na Pustyni Judzkiej cztery rękopisy biblijnego tekstu Księgi Amosa (trzy w Qumran i jeden w Wadi Murabba'at), cytaty w 4Q174 kol. 3, linii 12 (Am 9,11) oraz 4Q387 frag. 3, liniach 8-9 (Am 8,11), aluzja do Am 8,7 w 4Q387 frag. 3, linii 6, a przede wszystkim peszer do Am 5,26-27 znajdujący się w Dokumencie Damasceńskim (CD 7,14-19), świadczą o tym, że Księga Amosa cieszyła się stosunkowo dużą popularnością i uznaniem wśród członków społeczności qumrańskiej. Co więcej, cytowanie Księgi Amosa przy użyciu formuły wprowadzającej ,,jak zostało napisane” (4Q174 kol. 3, linia 12), „jak powiedział” (CD 7,14 i 16) świadczy - podobnie jak w przypadku innych ksiąg biblijnych (np. Pięcioksięgu, Iz, Jr) o tym, że Księga Amosa była traktowana w Qumran jako pismo autorytatywne.

Na szczególną uwagę zasługuje peszer do Am 5,26-27 w CD 7,14-19, w którym autor wykorzystuje tekst biblijnej Księgi Amosa, interpretując go w odniesieniu do sytuacji wspólnoty esseńskiej znajdującej się na wygnaniu w „Damaszku” i wprowadzając do

49 Zob. L. M o r a 1 d i, Imanoscritti di Qumran, s. 245; M. A. K n i b b, Interpreter of the Law, w: L. H. S c h if f m a n, J. C. V a n d e r K a m i in. (red.), Encyclopedia of the Dead Sea Scrolls, t. I, s. 384; C. He m p e 1, The Damascus Texts, Companion to the Qumran Scrolls 1, Sheffield 2000, s. 75-76; G. G. X e r a v it s, King, Priest, Prophet: Positive Eschatological Protagonists of the Qumran Library, s. 47; F. G a r c i a M a r t i n e z, Balaam in the Dead Sea Scrolls, s. 81; A. K u ś m i r e k, Balaam i jego wyrocznie (Lb 22-24) w tradycji targumicznej, s. 61-62; zob. także, G. J. B ro o ke, The Amos-Numbers Midrash (CD 7,13b-8,1a) and Messianic Expectations, ZAW 92/1980, s. 397-404; F. M. S t r i c k e r t, Damascus Document VII 1-20 and Qumran Messianic Expectation, RQ 12/1985-1987, s. 327-349. 
swojego komentarza aspekt eschatologiczny. Cytat z Am 5,26-27, który w Księdze Amosa jest częścią proroctwa o sądzie nad Izraelem z powodu praktykowania przez niego idolatrii, w Dokumencie Damasceńskim jest interpretowany jako proroctwo o zbawieniu odnoszącym się do wspólnoty. $\mathrm{Z}$ jednej strony autor CD nawiązuje do wydarzeń z początków historii wspólnoty, mówiąc o szacunku, jakim na wygnaniu wspólnota darzy Pismo Święte i właściwie interpretuje „Księgi Prawa” i „Księgi proroków”, a z drugiej zapowiada przyjście dwóch postaci mesjańskich, mianowicie „Wyjaśniającego Prawo”, tj. Mesjasza kapłańskiego, jak również „Księcia całego zrzeszenia”, tj. Mesjasza królewskiego. 